\title{
Concept of Corporate Parenting in the Hungarian Child Protection System
}

\author{
Andrea Rácz* \\ Institute of Political Science and Sociology, Department of Sociology and Social Policy, University of Debrecen, Hungary \\ *Corresponding author (Email: racz.andrea2@upcmail.hu)
}

\begin{abstract}
In the Hungarian Child Protection System 21000 children and young adults live. At present we do not have any research achievements relating what principles prevail in the planning and provision of care and services. It is essential that the children's individual needs define what kinds of services are needed and how these services can give adequate answers to the children's problems. In Hungary the planning and the provision of the services have ad hoc nature; it is not know exactly how the needs of the recipient determine the types of service they can get. Our research aims to answer how and what principles are prevailing in the development of the child protection's structure and what professional ideas are the development of foster and institutional care based on. How can the structure respond to those issues which can be identified in the child protection? In this study we examined the prevailing principles that determine practical work and professional concepts in relation of taking corporate parenting role and responsibility.
\end{abstract}

Keywords - Hungarian Child Protection System, Quasi-Professionalism, Corporate Parenting, Anomalies of the Child Protection System

\section{Introduction}

21000 children and young adults live in the Hungarian Child Protection System. In case of the children who were removed from their own family it is evident that the professional bodies and communities (educators, child welfare supervisors, foster parents) take parental responsibilities (corporate parenting), which means that all the governmental and official agencies in the institutional child protection care and the workers of the foster care network must work on making the lives of children in state care better. (Jackson, 2007)

It is essential that the children's individual needs define what kinds of services are needed and how these services can give adequate answers to the children's problems. (Trocmé, 1999; Unicef, 1997; Rácz, 2012) The regional operation is typically prevailed by less established professional principles; the planning and the provision of the services have ad hoc nature; in the child protection there is no conscious planning and the quasi-professionalism is typical. (Rácz, 2012) It is not know exactly how the needs of the recipient determine the types of service they can get.

\section{Subjects and Methods}

Currently we don't have any research result regarding how the care and services, provided by the child protection system, can serve the child's best interest, what operational mechanism determines the way of satisfying the children's needs and how the long-term care can promote social integration for those who were raised in the Child Protection System. The research, called 'Is the state a good parent? ${ }^{1}$, aimed to examine generally the prevailing principles that determine practical work and professional concepts in relation of taking corporate parenting role and responsibility. In this study we present the main results of the qualitative section of the research, which is based on 4 individual and 3 focus group interviews presenting the dysfunctions and system challenges of the Hungarian Child Protection System.

\subsection{Corporate parenting}

The children's affair is the expression of on one hand social solidarity and social self-interest on the other hand. The society expresses solidarity with the families when the families get proper provisions to raise their children and social self interest means that we consider the children as an investment for the future. The subject of politics, focused on children, is the children who depend on their families or other adults. (Kerezsi, 1996) According to Szilvási (2006) in the case of intervention, the followings should be examined: does the exact intervention enlarge the range of chances of the

\footnotetext{
1 The research financed by the University of Debrecen, Hungary (reference number: RH/885/2013).
} 
children and his/her parents? Does it strengthen the family bonds and mobilize internal and external resources? (so-called integrating interventions) Or does it do the opposite, for example tightens range of the chances and make the family-life insecure and the members be passive (so-called disintegrating interventions).

In the mainstream child protection, thinking over corporate parenting is hard to do, which is interpreted both on strategic and operative level. The corporate parenting not only means responsibility, but opportunity to enable children and young adults to have better future. The state can be considered as a good parent if it can take responsibility for the children in care, meet the personal needs and if it strives for the children to have the same achievements as their peers in school and other areas of life as well, just like any other responsible parent would like their child to have. (Scottish Government, 2008; Corporate parenting strategy for Clackmannanshire, 2009-2012)

Several criteria have to be examined in relation of foster parents, in order to be able to state that a foster parents does his/her parental role properly. The followings should be examined regarding the foster parents: Can she/he support the parents during the care? Does she/he admit their responsibilities for the children? Does she/he act for the child's well being? Does the foster parent have right self-knowledge in accordance with the standards of care? Is supervision available for him/her? Is she/he capable of communicate with the biological parents and deal with the potential conflicts? Does she/he use adequate methods regarding education? (Parent \& child fostering scheme procedures, 2010-2013) The capacity of foster parents has to be examined because in many cases the reason of unsuccessful placement is that the foster parent is unprepared for the challenges and they don't get support on system level. (Vida, 2001)

In Hungary, the Child Protection laws records as a basic principle that the official Child Protection always have to be preceded by voluntary services. The removal only can happen if the threatening conditions don't disappear in spite of multilateral services. According to its basic principle, the Hungarian Child Protection System is client-centered and the emphasis is on the meeting of children's needs (Domszky, 1999). In the following we examine how much is the system client-centered and how the children's needs are focused in practical operation, based on individual and group interviews.

\section{Results}

\subsection{Criticism of the system based on professionals' opinion}

The interviewed professionals provided summaries in relation of the Child Protection System' conditions, operating principles and main deficiencies.

One of the major problems is that Child Protection System's services, that aimed the target group, aren't differentiated properly. The few and different types of care often unable to provide real answers to the wide-ranging needs, the highly variable range of demand and challenges developing from real-life situations that is produced by unclear cases. Typically, it means problem for children who have unique and special needs. (Szikulai, 2006; Gyarmati Rácz, 2013)

When it comes to determine the place of care, the placement is typically accidental, Herczog (2001) states: viewpoint and interest are in contradiction with that the decision makers consider the children's best interest and the most optional solution during the placement. Changes in profession and in content of Child Protection are mostly because of individual initiations. Every legislator make the same mistake since 97', no one has ever tried to price these activities, which are included in the legislation. (...) The really expensive ones aren't realized. The most expensive one is the special care because it requires more professionals and additional criteria (...) there mustn't be hidden nook, theoretically a special separated place should be established in the Children's home, and the preparation of the staff, so there are a lot of factors which increase the cost of the care. As a result the maintainer often tired to evade it. This attitude can be understood in term of that the maintainers don't have enough money to sustain differentiated care. This reduces the opportunity of the professionals tremendously." - was said in an interview.

Deficiencies of the Child Welfare services also culminate as a serious problem in long-term care. The primary care cannot fulfill its preventive mission, those possibilities and preventive programs are missing exactly, that are based on participation that is voluntary and raised from the child's own needs, and which are not about the enforcement of the intervention and those possibilities and preventive programs are also missing which could eventually decrease the chance to get into primary care effectively. Of course, deficiencies have financial reasons primarily as well as the insufficient effectiveness of professionals who run sub-systems. (Szikulai 2006) ,,One of the major tasks of primary care is prevention (...). This kind of service is volatile. It is available but not sufficient. The day-time care contains an alternative day-time care part which hasn't been exactly defined yet. This would contain the preventive programs. (...) It has two reasons, one of is financial, because if I say more professionals are needed, it costs money, if I say more programs are needed that costs much money and the other one is structural framing. If the alternative day-time care isn't regulated by legislation, that is a structural problem. If the placement is determined just like it is done now, e.g. it doesn't say that we should place the child and maintain the place according to his/her needs then it is a structurally problem too. (...)" - said one of interviewees

Regarding the development of foster care, the workers preparation and selection criteria are also thematized. General view among the respondents, that the candidates for foster parents should be strictly filtered and trained well to have the professional standards to be raised.

However it is considered as a danger that under the new 
conditions foster parenting is becoming rather a tool to handle unemployment in the poor section of society than becoming unquestionable condition of sense of vocation that moves towards professionalism.

Regarding the system-wide changes, the experts participating in group interviews drew up the most important aimed goal: having real systematic changes, having the development materialized along a complex procedures/interventions, that takes into account the connection between the subdivisions.

In several group interviews, the system of allocation of financial funds, that are used to run the system, is discussed in details exactly that there are hidden possibilities in the reconsideration of provision. Carrying out the procedure of removal consistently, experience show that it is rarely effective and far from satisfactory in aware of the circumstances and available tools. For example it is often occurs that the removal happens nominally not because the family's financial inability but rather because of emerge of secondary problems (e.g., life skills deficiencies) in results of financial problems, but it is clearly concluded that if the financial problems are solved, the family can remain together.

\subsection{Is the state a good parent?}

By the questions themed on parental role of the state, the experts explain the state is accountable for as creator of legal regulations and operational framework, founder and maintainer of Child Protection System, but it cannot be expected the same as from a parent. It is important, however, that regarding establishment and development of the system, the decisions should be based on brad consensus and this constructive partnership is missing, the involvement of workers from different section and even in some cases of children, is neglected.

According the generally accepted approach, the state can replace family role and its success depends mainly on experts who work with the children. Their effectiveness depends on the framework of assumptions, which is available for them during work, including the range of available services and other tools, conditions of infrastructure, degree of workload and the extent of social prestige of the job. The support should be suited to the needs of the person in care, the current life situation of the service user taking into account the parents' situations and aspirations and the professionals must accordingly built up a clear goal and task system, keeping in mind that the workers who deal with people, with child protection background, those ,enter their lives and become a factor of that". (Domszky, 2004) The quality of the relationships between professionals, the degree of emotional support and motivation, the felt professional responsibility for the future/fate of the children and young adults, and the vision of the children's future provides safety not only on everyday level but through the professional collaboration provide stability over the period of care, laying the foundations for conditions of getting out (family reunification, starting an independent life) and can contribute to the successful child protection outcomes through ensuring care and education that are suited to the child's personal needs.

\section{Discussion}

The Hungarian Child Protection System is struggling from serious deficiencies and dysfunctions. The meeting of children's needs isn't ensured, the planning of placement is accidental, the development of care shows significant differences regionally, so it can occur that different issues become Child Protection problem in each region. The system is mainly unable to response to the needs of those children who have specific and unique needs. (Gyarmati \& Rácz, 2013)

In order to make the operation of child protection system, it is important to rethink the functions of the system and thematize the children's needs that are emerging. (Domszky, 2004, Herczog, 2001; Szikulai, 2006; Rácz, 2012) The stated policy aspiration and the actual developmental and transformational processes aren't consistent with each other. Beside putting the notion of family into center, the long-term care get special attention in the whole care-system during the developmental process, which have key role after the breakup of the family. Since the child protection system penetrate the family's autonomy, it is important for the professionals to take into consideration the rights of the children and the wishes of parents in a way to have the loss family relationship strengthened. (Pirjo Pölkki et al., 2011)

Overall the interviewed experts during the group interviews agree on that the state cannot be a ,good parent" as long as it doesn't make its professionals, who carry out the parental roles, to be good parents. i.e. made them to carry out their duties proactively such a way, they are satisfied with that and concentrating on their work.

Solving the problem of child protection requires supplier responses only from child protection, just like the child protection doesn't have exclusiveness to solve the problems. At the same time in the spirit of corporate parenting, it can be expected from the state to provide quick and effective supports for children and parents i.e. to integrate and mobilize the internal and external resources of the family and the child, if the state has to provide protection outside the family, there should be institutionalized grants for every kind of care, in term of each person, who take parental role, treat the children to correspond all the criteria of good parenthood. Recognition regarding the importance of individual responsibility, individual performance in the complex challenges regarding education and care, can be the clue to have the operation of the child protection to move towards professionalization, but of course the presence of system requirements for this is essential.

\section{References}

Corporate parenting strategy for Clackmannanshire (2009-2012). 
Domszky, A. (1999). Gyermek- és ifjúságvédelem (Jegyzet). Budapest: Államigazgatási Föiskola.

Domszky, A. (2004). A gyermekvédelmi szakellátás értékháttere, a szakellátás alapértékeinek érvényesülését szolgáló biztosítékok, módszerek, technikák. In Domszky A. (Ed.), Gyermekvédelmi szakellátás - segédanyag szociális szakvizsgához (pp. 45-49) Budapest: NCSSZI.

Gyarmati, A., \& Rácz, A. (2013). Kutatási eredmények - A gyermekvédelemben nyújtott ellátások és szolgáltatások tervezésével kapcsolatos kutatás eredményei. Együtt a gyermekvédelemben: tájékozottság, együttmüködés, biztonság, (10), 1-3.

Herczog, M. (2001). Gyermekvédelmi kézikönyv. Budapest: KJK-Kerszöv.

Jackson, S. (2007). Care leavers, exclusion and access to higher education. In Abrams, D. \& Christian, J. \& Gordon, D. (Eds.), Multidisciplinary Handbook of Social Exclusion Research. (pp. 115-135) Chichester: John Wiley \& Sons.

Kerezsi, K. (1996). Gyermek, család, társadalom. In Szilvási L. (Ed.), Gyermek - család - társadalom. Szociális munka gyermekes családokkal. (pp. 25-55) Budapest: Hilscher Rezső Szociálpolitikai Egyesület és ELTE Szociológiai Intézet Szociálpolitika Tanszéke.

Parent \& child fostering scheme procedures (2010-2013). (Policy \& Performance Manager (LAC), Children, families and education Children's social services) KENT County Council

Pirjo Pölkki, V., Pohjanpalo, H., \& Miettinen, J. (2011). The possibilities for effective child protection - The Finnish research perspective. ERIS web journal (1), 13-33. Retrieved January 20, 2014 from http://periodika.osu.cz/eris/dok/2011-01/possibilities_for_effective_ch ild_protection.pdf

Rácz, A. (2012). Barkácsolt életutak, szekvenciális (rendszer) igények. Budapest: L'Harmattan.

Szikulai, I. (2006). A magyar gyermekvédelem fejlődésének kulcskérdései egy lehetséges szakmai stratégia lépései. In Rácz A. (Ed.), A magyar gyermekvédelmi rendszer helyzete, jövőbeli kihívásai Budapest: NCSSZI, CD-ROM.

Szilvási, L. (2006). Családok a gyermekvédelem határán. In Rácz A. (Ed.), A magyar gyermekvédelmi rendszer helyzete, jövőbeli kihívásai. Budapest: NCSSZI, CD-ROM.

These Are Our Bairns - a guide for community planning partnershipson being a good corporate parent. (September 2008) Edinburgh: Scottish Government.

Trocmé, N. (1999). Canadian Child Welfare Multi-Dimensional Outcomes Framework and Incremental Measurement Development Strategy. In Thompson, J. \& Fallon, B. (Eds.), The First Canadian Roundtable on Child Welfare Outcomes - Roundtable Proceedings. (pp. 30-54) Toronto, Ontario: University of Toronto Press.

UNICEF Innocenti Research Center (1997). Children at risk in Central and Eastern Europe: perils and promises. Regional Monitoring Report No. 4. Florence, Italy: The United Nations Children's Fund. Retrieved November 7, 2007 from http://www.unicef-irc.org/databases/transmonee

Vida Zs. (2001). Sikertelen nevelőszülői kihelyezések. Család, gyermek, ifjúság. (3), 67-71 